\author{
Krzysztof Kołodziejczyk \\ https://orcid.org/0000-0002-3262-311X \\ University of Wrocław \\ Faculty of Earth Sciences and Environmental Management \\ Department of Regional Geography and Tourism \\ krzysztof.kolodziejczyk@uwr.edu.pl
}

\title{
HERITAGE TRAM LINES IN WROCŁAW: ANALYSIS OF THE TOURIST OFFER FROM AN URBAN TOURISM PERSPECTIVE
}

\begin{abstract}
The aim of the article is to assess the operation of Heritage Tram Lines in Wrocław in 2018 in terms of the attractiveness of the offer for tourists, uptake, the costs of its maintenance and profitability, to finally indicate some general conclusions on this urban tourism offer. The present moment is special as an increase in carriers (transport companies) operating the Lines from one to two has enabled various changes to be made. Based on data on the number of tickets being sold it is possible to assess that the Lines are most popular in July and August, however even then statistically less than half of the seating places are occupied. Trips with a guide are less frequented than rides without. As a consequence, in this article several suggestions are presented which may help the Lines become more popular: for example a longer period of operation (in a day and in a year), the introduction of new ticket types and additional attractions.
\end{abstract}

Keywords: technical heritage, heritage tram cars, transport, tourist tram lines, Wrocław.

\section{INTRODUCTION}

In most cities with a developed tourist function there is an offer of special public transport routes (Mehring, 2017) which are intended to bring tourists to the more important points of interest (tourist attractions) or show them the main sights in the shortest possible time. In some cases, these routes can become in themselves a tourist attraction, operating in the form of an independent tourist product (see Kaczmarek, Stasiak, Włodarczyk, 2010; Meyer, 2015). Such routes are most often served by modern, specially adapted vehicles (e.g. double-decker buses with an open top in Great Britain, but also in many other European cities, e.g. Berlin), but in some cities - with heritage public transport vehicles - historic tram cars run on these routes which make the offer more attractive. Due to its special character, the second is particularly appreciated by tourists which is best illustrated by the examples of Lisbon and Porto in Portugal or San Francisco in the USA.

In Poland in most of the cities where there is tram transport, the operators maintain tourist routes served by historic tram cars (see Kołodziejczyk, 2018). Such an offer is available in Bydgoszcz, Częstochowa, Elbląg,
Gdańsk, Kraków, Łódź, Poznań, Szczecin, Warsaw and Wrocław. These routes have a different period of operation (usually weekends, generally in the summer half of the year or only at holidays), length, frequency, and age of the tram cars used, so comparing them is quite difficult. This article presents a closer look at the Heritage Tram Lines that run in Wrocław. It is interesting that (unlike other cities) its operator is not an urban carrier serving other regular lines, but a voluntary society. Moreover, the operation is financed by the Municipal Office of Wrocław on the basis of a competition for nongovernmental organizations. Such a situation raises some technical and administrative difficulties, but on the other hand, it gives more freedom in shaping the offer, and at the same time allows a wide involvement of enthusiasts of history, technology and, particularly, old trams (or buses). It is worth emphasizing that the capital of Lower Silesia can be proud of the largest collection of historic public transport vehicles in Poland (Kołodziejczyk, 2012, 2018; Sielicki, 2013). This reflects in a good way the changes that have occurred in public transport in Wrocław from the horse-drawn trams launched in 
1877 (Sielicki, 2017), through electric trams in 1893, up to the transformations that took place from the mid-20 th century whose purpose was to adapt public transport to ever more intensive vehicular traffic, and an increasing number of inhabitants and passengers (Bufe, 1992; Lewandowski, Molecki, 2006; Maciejewski, 2004; Sielicki, 2012a, 2012b; Wojcieszak, 1993). Unfortunately, the condition of individual vehicles in this collection is very diverse, from technically efficient to complete wrecks (Sielicki, 2013).

The offer of tourist routes served by historic rolling stock on the one hand is a part of urban tourism, and on the other, heritage tourism (however, both concepts overlap). In the simplest terms, urban tourism includes all forms of tourism taking place in cities (Matczak, 1989; Marak, Wyrzykowski, 2010), but at the same time these can be "forms of tourism related to the values and tourist infrastructure occurring in urban areas" and "tourism, which aims to visit and get familiar with a city treated as cultural heritage and considered an indivisible element of tourism space" (Kowalczyk, 2005, p. 157; see Ashworth, 1992; Mika, 2007a; Page, 1995; Sala, 2012). Trams or public transport are elements of the urban landscape in operation at least since the $19^{\text {th }}$ century, hence the role of heritage associated with them can be one of the most important objects of interest for urban tourists (at the same time, such a tourist travels through the city using this means of transport). Historic means of public transport also show changes in ways of traveling and technological development, becoming part of the tourism of cultural heritage understood as exploring places, sites of material and spiritual culture and activities that show the historical and cultural values of the past and present in an authentic way (Lipinska, 2011). In the case of this type of tourism, the close contact of its participants with historic sites is extremely important (Mikos von Rohrscheidt, 2008), which in the case of a tourist route operated by historical tram cars is probably the greatest. The offer analysed can be associated with automotive tourism, however, unlike its usual form (Marak, Wyrzykowski, 2010; Mika, 2007b) the mode of transport is not the main reason but in fact the motivation is to visit sites related to its development (e.g. automotive museums, car factories, connected events). This type of tourism has had few academic studies so far (Cudny, 2018; Cudny, Horňák, 2016) but this concept is quite common in the transport enthusiasts' environment (which is manifested, among others, by the internet service Turystyka-motoryzacyjna.pl). So far, there is very little academic research focused on the operation of tourist routes served by historic tram cars (see Kołodziejczyk, 2011).

The aim of the article is to assess the operation of the tourist tram lines in Wrocław through its offer - its attractiveness to tourists and uptake, as well as the costs of maintenance and profitability. Firstly, a desk analysis of available promotional materials related to the Lines was carried out to define the way it operates. A valuable source of information was data on the sale of tickets over the whole season by type of ticket and individual routes, which was then subjected to a statistical analysis aimed at determining uptake at both overall and particular periods of operation. Financial data on total revenues and expenses was also obtained allowing the question of whether such a line could be maintained without subsidies could be answered. The results were used for a SWOT analysis (Tylińska, 2005), which is quite often used in the tourism research, not only in the context of reception areas (Goranczewski, Puciato, 2010) but also specific tourist attractions (Kruczek, 2011; Nowacki, 2000). In the final part of the work, recommendations were made regarding the improvement (development) of the existing offer.

\section{OPERATION OF THE HERITAGE TRAM LINES IN 2018}

Heritage Tram Lines have been running in Wrocław since 2009 and were commissioned by the Municipal Office of Wrocław (currently the City and Tourism Promotion Office), but so far it has been operated exclusively by the Wrocław Admirers Society (Polish: Towarzystwo Miłośników Wrocławia, TMW). In 2018, for the first time, a consortium of two associations became the operator, to which, apart from TMW, the Urban Transport Enthusiasts Club (Polish: Klub Sympatyków Transportu Miejskiego, KSTM) entered. This allowed a greater diversification because the consortium now provided four tram cars (Fig. 1): Linke-Hofmann Standard Juliusz ${ }^{1}$ from 1929 (TMW), Konstal 4N1 Enusia from 1960 (KSTM), Konstal 102N Strachotek from 1969 (TMW) and a Konstal 102Na from 1972, comprehen-

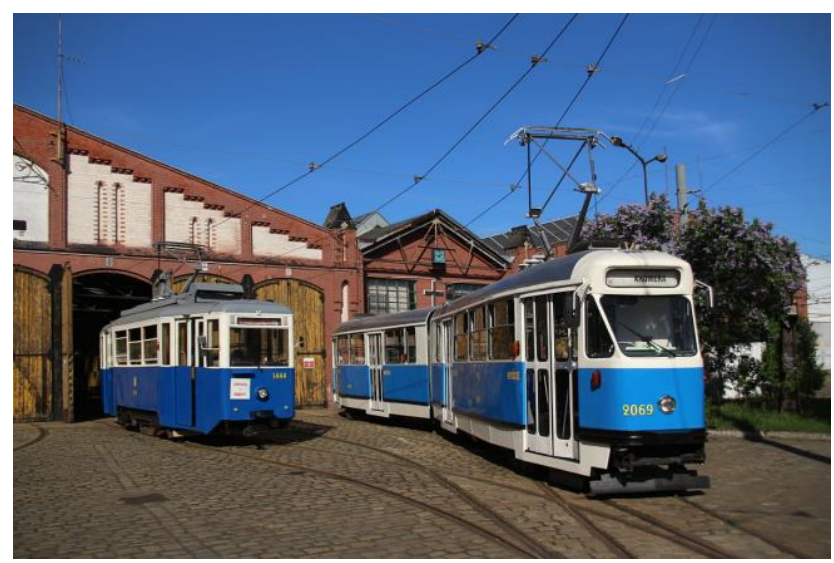

Fig. 1. Trams operating on Routes A and B of Heritage Tram Lines: Konstal 4N1 from 1960 and the Konstal 102Na articulated tram car from 1972 Source: Kołodziejczyk, 2018 
sively renovated in 2014-2018 (KSTM). Apart from the Linke-Hofmann Standard tram, all tram cars have a sound system. In relation to the previous year, some changes were introduced concerning routes, prices and organization, e.g. by planning several stops near the most important tourist attractions. Intermediate stops had also existed at the beginning (from 2009 to around 2012), but later TMW abandoned them.

Heritage Tram Lines in 2018 ran from June $16^{\text {th }}$ to September $9^{\text {th }}$ on Saturdays and Sundays from 12:00 to 21:00 over four routes (Fig. 2) which all shared the stylized stop on Theatre square ( $\mathrm{pl}$. Teatralny), adjacent to the Opera House and about $400 \mathrm{~m}$ from the Market Square. Route A led from the Opera to the Centennial Hall (inscribed on the UNESCO World Heritage List) and the Zoological Garden, and Route B in the opposite direction, but other streets, which allowed tourists to see various monuments and attractions along the way (including the District of Four Religions, Royal Palace, churches of St. Christopher and St. Adalbert, National Museum, Ostrów Tumski, Szczytnicki Park, Zwierzyniecki Bridge, church of the Virgin Mary on Piasek Island, Market Hall, Ossolineum, Main Building of the University of Wrocław, Arsenal). The whole round trip took just over 90 mins with a half-hour stop near the Centennial Hall allowing a quick view of the historic building and its surroundings (there was of course the possibility of returning with another, later tram). Each of Routes C and D was circular and, in contrast, there were no stops on the way. The first led through the Old Town and the recently revitalized Nadodrze district, the ride took about 50 minutes, while the second, planned as an evening route, was supposed to show the most interesting illuminated monuments in just over half an hour (including the Renoma Department Store, Main Railway Station, Ostrów Tumski churches, Main Building of the University of Wrocław). In this case, only one run took place at 20:00, which, unfortunately, for most of the time when the line was in operation was simply too early to see the illumination of the buildings. Routes A and B were served by KSTM, while $\mathrm{C}$ and D were by TMW. On all routes on selected runs a licensed guide talked about the monuments and other attractions being passed. In the case of Routes A and B, during the stop at the Centennial Hall the guide also showed passengers around. It was purposely proposed to provide a guide service on selected runs only (6 out of 11 each day) to provide a choice. For some tourists or Wrocław inhabitants it is an attraction just to take a ride on a historic tram car and watch the city from its windows.

In the case of tourist routes the 'hop on-hop off' offer is often and successfully used in many Western cities, and more recently on Polish routes of this kind.

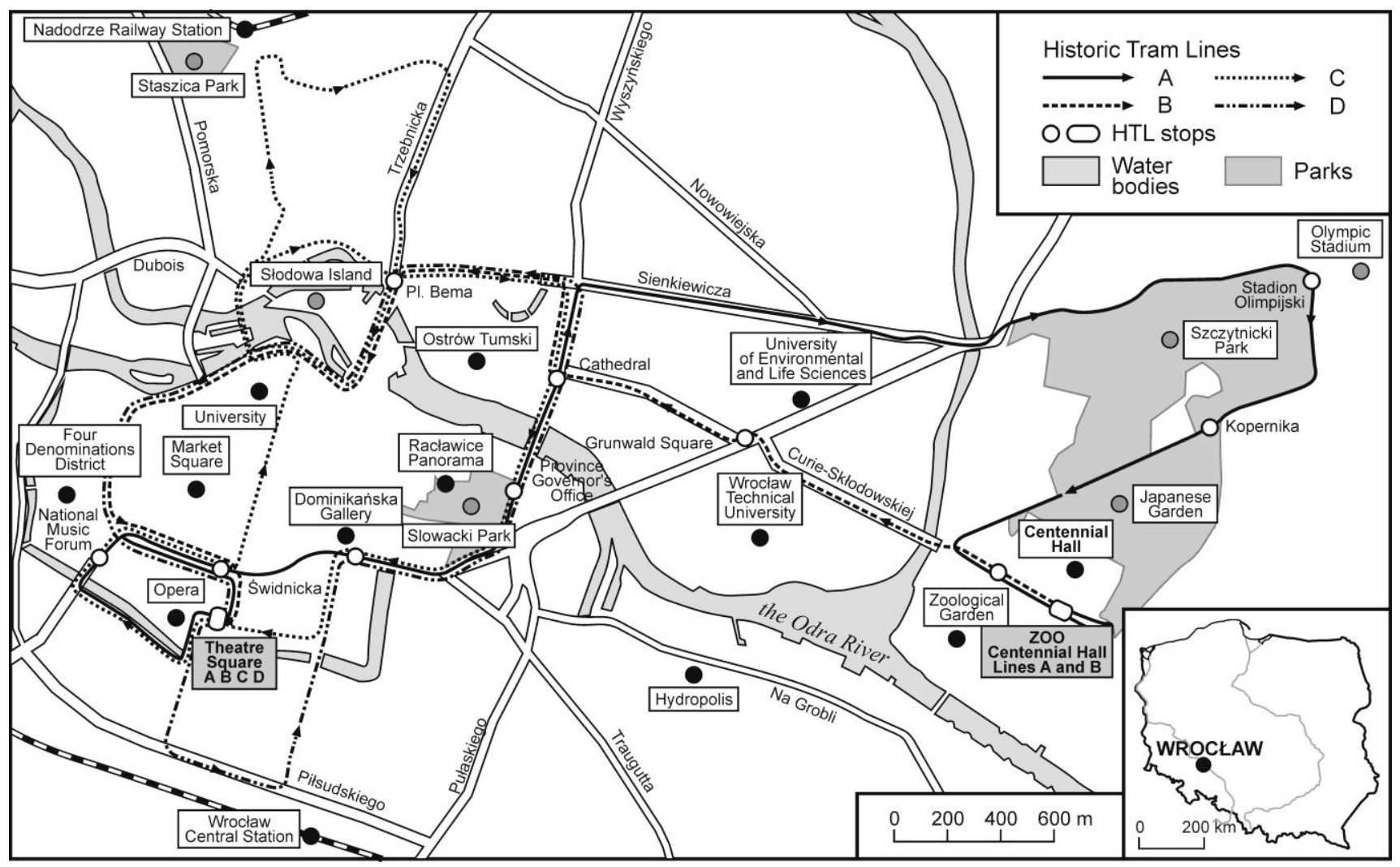

Fig. 2. Map of the four routes of Heritage Tram Lines in 2018

Source: elaboration: T. Szymczyszyn \& K. Kołodziejczyk; base map: OpenStreetMap authors 
In connection with its use on Heritage Tram Lines in Wrocław and the designation of several stops on Routes A and B, KSTM introduced a conductor whose main task was to sell tickets. In addition, conductors, recruited from public transport enthusiasts, if necessary informed passengers about the history and technical details of the tram which performed the run. They were equipped with historic hand-held punches. Tourists could thus ride the entire route they chose, which allowed them to quickly and easily get acquainted with the majority of the main tourist attractions of the city (Routes A, B, C and D), or they could get off and on at stops located near monuments for more detailed sightseeing (Routes A and B).

The disadvantage of the tariff was a lack of one-day tickets, which would allow free use of the entire offer on all four routes, a result of the potential difficulty of dividing revenues between the two carriers. There were only one-way tickets (for all routes) and return tickets (for routes $\mathrm{A}$ and $\mathrm{B}$ ): full-price, concessionary and family (two adults and up to three children). Full-price and concessionary one-way ticket tariffs were imposed by the Municipal Office of Wrocław, while the others were chosen by the carriers. The organisation and, above all, the way of settling the revenues from tickets, made it impossible to establish wider cooperation with managers of other tourist attractions, even those owned by the city. However, it could be advisable to offer joint tickets with the Zoological Garden or Centennial Hall, to which some of the historic trams brought tourists.

Polish-English leaflets were published advertising Heritage Tram Lines with a route map, timetable and price list, available at all tourist information points in the city, as well as illustrated leaflets with an outline of tram communication history in Wrocław, given free of charge as a form of souvenir. Because the task was co-financed from public funds, Wrocław Municipal Office did not allow postcards depicting historic tram cars or other souvenirs to be sold, which would have made the offer more attractive. In addition to leaflets, promotion was carried out through the websites of the local government in Wrocław and of both carriers (in Polish and English, partly also in German), articles in the local press and on various websites (including Krzeszowski, 2018; Ostatnie weekendy..., 2018; Wrocławska Zabytkowa Linia Tramwajowa..., 2018; Zabytkowa Linia Tramwajowa..., 2018), as well as on social networks where information about vehicles running on a given day or changes of routes resulting from track repairs were published. The whole promotional campaign was conducted jointly by both carriers and a combined offer was advertised. The routes were also popularised by some guide groups.

It must be emphasised at the same time that the use of historic trams in Wrocław is not limited to seasonal, regular tram lines. All working tram cars can be rented for commercial trips, such as the transport of tourists with a guide's commentary (which is especially popular in the case of German groups), school groups, wedding guests or as part of events organised by companies (e.g. integration evenings). Trams also participate in photo sessions and run during various events taking place in the city, although in this case the activity of KSTM is greater than that of TMW. The most important event is Museums Night when historic trams and buses provide connections between facilities opened to the public, being at the same time an attraction in themselves (the largest such project is in Warsaw, but for three years special museum routes operated by historical tram cars have also been launched in Wrocław). Other events in which historical trams take part include the Feast of Wrocław and the European Week of Sustainable Transport, as well as various events organised by cultural institutions (e.g. the National Museum or the Institute of National Remembrance - Polish: Instytut Pamiecci Narodowej). The former Popowice tram depot, where the historic public transport trams are based, is not regularly open to visitors because of its inadequacy for such a function and the lack of funds for renovation and maintenance. The facility is, however, occasionally made available, e.g. for several years at the beginning of September Popowice Depot Open Day is organised, each time attracting several thousand people.

\section{SALE OF TICKETS ON HERITAGE TRAM LINES IN 2018}

The basic information about the tourist use of Heritage Tram Lines is derived from ticket sales data, prepared by KSTM and divided into individual days and runs, but by TMW only for three financial periods, ${ }^{2}$ which unfortunately hinders a more detailed analysis for the entire offer. Of the over 2,000 tickets sold, the largest share were concessionary and full-price one-way tickets ( $44.42 \%$ and $26.03 \%$ respectively, Table 1$)$. This is because only one-way tickets are available on Routes C and D, although these types of tickets are also quite popular on Routes A and B (third and first place respectively). What draws attention - and is quite difficult to explain - is the reverse proportion between full-price and concessionary one-way tickets sold by the carriers. In the case of KSTM, the number of full-price tickets sold was almost twice as high as concessionary ones, while in the case of TMW the latter were almost four times more popular. Maybe this can be explained by the ignorance of new tariffs by TMW employees, because on circular routes around the city centre in previous years tickets for 4 PLN were valid, unlike the 8 PLN in 2018. Another reason could have been less encouragement to buy family tickets, whose share in the case of TMW is only 
Table 1. Sale of tickets on the Heritage Tram Lines in 2018, divided into types of ticket

\begin{tabular}{|c|c|c|c|c|c|c|c|}
\hline \multirow[t]{2}{*}{ Specification } & $\begin{array}{c}\text { Full-price } \\
\text { one-way }\end{array}$ & $\begin{array}{c}\text { Concessionary } \\
\text { one-way }\end{array}$ & $\begin{array}{c}\text { Family } \\
\text { one-way }\end{array}$ & $\begin{array}{l}\text { Full-price } \\
\text { return }\end{array}$ & $\begin{array}{c}\text { Concessionary } \\
\text { return }\end{array}$ & $\begin{array}{l}\text { Family } \\
\text { return }\end{array}$ & \multirow[t]{2}{*}{ Total } \\
\hline & 8 PLN & 4 PLN & 16 PLN & 12 PLN & 6 PLN & 24 PLN & \\
\hline $\begin{array}{l}\text { The total number of tickets sold on } \\
\text { all routes }\end{array}$ & 525.00 & 896.00 & 137.00 & 229.00 & 145.00 & 85.00 & $2,017.00$ \\
\hline $\begin{array}{l}\text { The average number of tickets sold } \\
\text { on all routes per day of operation }\end{array}$ & 20.19 & 34.46 & 5.27 & 8.81 & 5.58 & 3.27 & 77.58 \\
\hline $\begin{array}{l}\text { Number of tickets sold } \\
\text { on Routes A and B }\end{array}$ & 344.00 & 194.00 & 74.00 & 229.00 & 145.00 & 85.00 & $1,071.00$ \\
\hline $\begin{array}{l}\text { Number of tickets sold } \\
\text { on Routes C and D }\end{array}$ & 181.00 & 702.00 & 63.00 & - & - & - & 946.00 \\
\hline $\begin{array}{l}\text { Total revenue from the sale of } \\
\text { tickets on all routes (in PLN) }\end{array}$ & $4,200.00$ & $3,584.00$ & $2,192.00$ & $2,748.00$ & 870.00 & $2,040.00$ & $15,634.00$ \\
\hline $\begin{array}{l}\text { Average revenue from the sale } \\
\text { of tickets on all routes per } \\
\text { day of operation (in PLN) }\end{array}$ & 161.54 & 137.85 & 84.31 & 105.69 & 33.46 & 78.46 & 601.31 \\
\hline $\begin{array}{l}\text { Revenue from the sale of tickets } \\
\text { on Routes A and B (in PLN) }\end{array}$ & $2,752.00$ & 776.00 & $1,184.00$ & $2,748.00$ & 870.00 & $2,040.00$ & $10,370.00$ \\
\hline $\begin{array}{l}\text { Revenue from the sale of tickets } \\
\text { on Routes C and D (in PLN) }\end{array}$ & $1,448.00$ & $2,808.00$ & $1,008.00$ & - & - & - & $5,264.00$ \\
\hline
\end{tabular}

Source: author.

$6.66 \%$, while for KSTM - 14.85\% (one-way and return in total, only one-way $-6.90 \%$ ). In the case of Routes A and $\mathrm{B}$, the most popular were full-price one-way (32.12\%), full-price return $(21.38 \%)$, concessionary oneway $(18.11 \%)$ and concessionary return tickets $(13.54 \%)$. However, it should be remembered that between three and five people could use a family ticket, hence their share in terms of the number of transported passengers was much higher.

When it comes to revenues from ticket sales, the situation is a bit different due to varying prices (Table 1). In total for all routes the largest income was generated by full-price and concessionary one-way tickets $-26.86 \%$ and $22.92 \%$ respectively, followed by full-price return tickets $(17.58 \%)$ and family one-way and return tickets $(14.02 \%$ and $13.05 \%)$. In the case of routes serviced by KSTM, the revenues from the sale of full-price one-way and return tickets $(26.54 \%$ and $26.50 \%)$ were almost identical. Shares of both types of family tickets $(19.67 \%$ for return tickets and $11.42 \%$ for one-way) were also quite significant. Therefore, it should be acknowledged that the introduction of return and family tickets met the interest of tourists, many of whom travelled the whole length of Routes A and B. This applies in particular to families who almost twice as often purchased return tickets than those valid for only one journey. It should be emphasised that all the revenues from the tickets had to be spent on Heritage Tram Lines, particularly on the maintenance of trams.

On the basis of data on the number of tickets sold, it is possible to assess the extent of usage of the offer, i.e. the ratio of the actual number of transported passengers to the potential maximum number. ${ }^{3}$ It is assumed that the most optimal form is, of course, a ride with a seat, although standing in trams is allowed. The trams usually running on Saturdays had 32 and 16 seats, respectively, and on Sundays, 32 seats each. Taking into account the number of runs each day, they could carry as many as 272 people seated each Saturday and 352 each Sunday. However, taking into account the number who could purchase a given type of ticket (Table 1), the offer was used on average by about 119 to 143 per day. ${ }^{4}$ Statistically, therefore, less than half of the seating places were occupied. On the scale of the whole season, potentially Heritage Tram Lines could carry 8,112 seated passengers, but in reality there were from 3,090 to 3,704, so the usage was from $38.09 \%$ to $45.66 \%$. It is worth checking these figures for both carriers separately. In the case of KSTM, assuming that the Konstal $102 \mathrm{Na}$ tram car with 32 seats was operating throughout the entire season (on a few occasions the smaller Konstal 4N1 car with 16 seats appeared), the total potential number of passengers was 4,992. Actually, it transported from 2,018 to 2,506, which gives a rate of $40.42-50.20 \%$. In turn, TMW out of 3,121 potential passengers had in fact from 1,072 to 1,198 , hence a slightly lower usage of $34.36-38.40 \%$.

Detailed data on ticket sales for individual runs is available only for Routes A and B (Table 2). It is clearly visible that most people used the historic trams running from the city centre to the Centennial Hall, i.e. those starting at the Opera stop at 12:00, 14:00 and 16:00. On these three runs, during the entire period of operation, a total of 816 tickets were sold, $76.19 \%$ of all tickets distributed by KSTM. The most popular was the 14:00, and the least 17:15 (last return from Centennial Hall to the city centre). Taking into account the pairs (there 
and back), the highest number of tickets was sold for the second pair and the lowest for the third, which is surprising as in the case of Routes A and B these were the only runs offered with a guide service. Taking into account the relatively high popularity of the run at noon, one may wonder whether Heritage Tram Lines should not start earlier, providing access to the Centennial Hall, Zoological Garden and Szczytnicki Park (traditional leisure places for the inhabitants of Wrocław) from the morning so that it would be possible to spend the whole day there.

The share of individual types of ticket sold on specific runs is quite diverse (Table 3 ). In the case of runs starting at the Opera House, during the first one (12:00) more one-way tickets were sold, in particular full-price, and during the second (14:00) return tickets, with a significantly higher proportion of concessionary. The share of return tickets for the last run from the Opera (16:00) is also quite high. Such a result can be equated with the offer of a guide available at that time, but, on the other hand, it is quite surprising as return tickets were valid for the whole day (there was no need to go back on the same tram), so planning for a longer stay in recreational areas in the eastern part of the city, it would be more logical to start the journey as early as noon. The slightly higher share of family return tickets during guided tours (16:00) is noteworthy. In the case of journeys in the opposite direction (from the Centennial Hall to the centre), runs at 13:15 showed a greater share of return tickets, which in turn were sold relatively little at 15:15 (at 17:15 return tickets were not sold because the tram was not going back to the Centennial Hall). However, the data presented must be treated with some reserve, because with quite small numbers of tickets of each type sold, the results could have been influenced by organised groups that were also able to use the offer. For example, with the appearance of several large groups of children, the percentage of concessionary tickets could have been overstated. This could be an attempt to explain a clearly higher percentage of concessionary return tickets on runs at 14.00 .

The problem in terms of the promotion of Heritage Tram Lines are the differing dates in individual years of the beginning and end of its operation. Initially (in 2009-2011) it ran throughout the year, later usually from the long weekend at the beginning of May to autumn, and most recently from June to September. This results from problems with financing the project. Varying the dates and the shorter period of operation means that the residents of Wrocław are not so used to this offer, while they constitute a significant (at certain periods of time) percentage of passengers. Each year, therefore, the offer must be promoted from scratch, which is reflected by relatively low (but gradually growing) revenues from tickets during the first weekends of activity (Fig. 3). Because on Routes A and B in 2018 some tram cars were not yet running on the Lines (in particular Konstal $102 \mathrm{Na}$, which only had a premiere after renovation two months earlier), during the first weekend the 'novelty effect' acted and the revenues were quite high,

Table 2. Number of tickets sold on Routes A and B of Heritage Tram Lines in 2018, divided into types of ticket and individual runs

\begin{tabular}{|c|c|c|c|c|c|c|c|}
\hline \multirow{3}{*}{ Tram run } & \multicolumn{3}{|c|}{ One-way tickets } & \multicolumn{3}{|c|}{ Return tickets } & \multirow{3}{*}{ Total } \\
\hline & full-price & concessionary & family & full-price & concessionary & family & \\
\hline & 8 PLN & 4 PLN & 16 PLN & 8 PLN & 4 PLN & 24 PLN & \\
\hline $12: 00$ & 97 & 34 & 18 & 68 & 35 & 25 & 277 \\
\hline $13: 15$ & 21 & 23 & 10 & 15 & 8 & 5 & 82 \\
\hline $14: 00$ & 71 & 44 & 14 & 80 & 72 & 20 & 301 \\
\hline $15: 15$ & 46 & 35 & 11 & 2 & 1 & 8 & 103 \\
\hline 16:00 & 66 & 38 & 14 & 64 & 29 & 27 & 238 \\
\hline $17: 15$ & 43 & 20 & 7 & 0 & 0 & 0 & 70 \\
\hline Total & 344 & 194 & 74 & 229 & 145 & 85 & 1,071 \\
\hline
\end{tabular}

Source: author.

Table 3. Share (in \%) of individual types of ticket sold on Routes A and B of Heritage Tram Lines in 2018, divided by run

\begin{tabular}{|l|c|c|c|c|c|c|c|}
\hline \multirow{3}{*}{ Tram run } & \multicolumn{3}{|c|}{ One-way tickets } & \multicolumn{3}{c|}{ Return tickets } & \multirow{2}{*}{ Total } \\
\cline { 2 - 8 } & full-price & concessionary & family & full-price & concessionary & family \\
\cline { 2 - 8 } & 8 PLN & 4 PLN & 16 PLN & 8 PLN & 4 PLN & 24 PLN & \\
\hline $12: 00$ & 35.02 & 12.27 & 6.50 & 24.55 & 12.64 & 9.03 & 100.00 \\
\hline $13: 15$ & 25.61 & 28.05 & 12.20 & 18.29 & 9.76 & 6.10 & 100.00 \\
\hline $14: 00$ & 23,59 & 14.62 & 4.65 & 26.58 & 23.92 & 6.64 & 100.00 \\
\hline $15: 15$ & 44.66 & 33.98 & 10.68 & 1.94 & 0.97 & 7.77 & 100.00 \\
\hline $16: 00$ & 27.73 & 15.97 & 5.88 & 26.89 & 12.18 & 11.34 & 100.00 \\
\hline $17: 15$ & 61.43 & 28.57 & 10.00 & 0.00 & 0.00 & 0.00 & 100.00 \\
\hline
\end{tabular}

Source: author. 
but during the next they turned out to be the lowest in the whole season (Fig. 3; the weather was good so it is hard to see it as the reason for low attendance). Revenues in July and August on these routes remained at a fairly high, stable level (Fig. 3), usually reaching over 400 PLN a day (466.47 PLN on average). This took place despite the launch from June $30^{\text {th }}, 2018$ by MPK Wrocław (the municipal carrier) a competitive route served by a tram from the 1950s. At the beginning of September, a fall in revenues was recorded, which may suggest

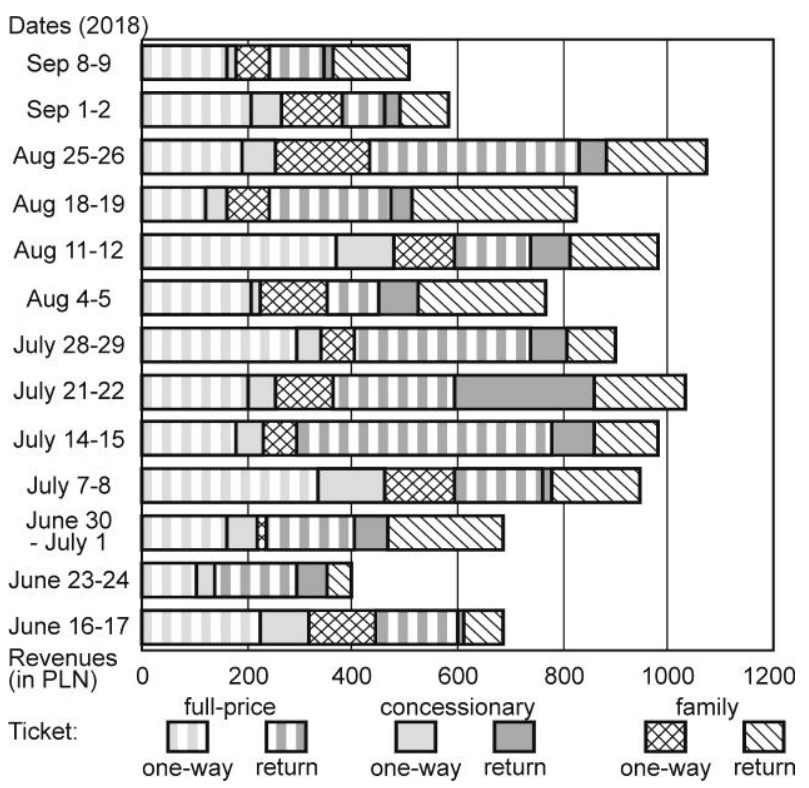

Fig. 3. Revenues (in PLN) from the sale of tickets on Routes A and B during individual weekends of running Heritage Tram Lines in 2018

Source: author a typical seasonal (holiday) character of demand for travel with historic trams. On the other hand, with a longer period of operation, it would be more clearly embedded in the minds of both Wrocław inhabitants and some tourists, and consequently, higher uptake and income can be expected (which, of course, will vary between the holiday period and the school year). This is evidenced by a comparison of ticket sales during the first and last weekends of the school holidays, and at the same time during the second and penultimate weekend of running the Lines (see attachments). The results are more beneficial in the second case, when the Lines were present in the city space for a longer time (the weather on both weekends was comparable - mostly sunny and warm). Taking into consideration the sale of particular types of tickets on specific days (Fig. 3), a considerably higher share of full-price one-way tickets can be seen on July $8^{\text {th }}$ and $29^{\text {th }}$, and August $11^{\text {th }}$, family one-way tickets on August 25 $5^{\text {th }}$, full-price return tickets on July $14^{\text {th }}, 15^{\text {th }}$ and $29^{\text {th }}$, and August $25^{\text {th }}$, and concessionary return tickets on July $21^{\text {st }}$ (result of a visit of an organised group).

\section{PROFITABILITY OF OPERATION AND A SWOT ANALYSIS}

The costs of operation of Heritage Tram Lines differs slightly depending on the carrier (Table 4), which results from technical conditions (e.g. the differing power of trams causes different costs of energy consumption) and administrative reasons (e.g. part of the work is performed on the basis of volunteering by members

Table 4. Costs (in PLN) of the operation of Heritage Tram Lines in 2018

\begin{tabular}{|l|c|c|}
\hline \multicolumn{1}{|c|}{ Specification } & $\begin{array}{c}\text { Urban Transport Enthusiasts } \\
\text { Club (Klub Sympatyków } \\
\text { Transportu Miejskiego) }\end{array}$ & $\begin{array}{c}\text { Wrocław Admirers Society } \\
\text { (Towarzystwo Miłośników } \\
\text { Wrocławia) }\end{array}$ \\
\hline Power consumption by trams & $7,662.85$ & $8,097.87$ \\
\hline Readiness of the technical emergency service & $6,251.59$ & $5,498.10$ \\
\hline $\begin{array}{l}\text { Using the infrastructure of the local government in } \\
\text { Wrocław (tracks and traction network) }\end{array}$ & $1,762.63$ & $1,448.11$ \\
\hline Tram-drivers' work & $5,070.00$ & $4,680.00$ \\
\hline Conductors' work & $\begin{array}{c}\text { (,225.00 } \\
\text { (volunteering) }\end{array}$ & $5,441.00$ \\
\hline Tourist-guides' work & $3,750.00$ & $8,032.76$ \\
\hline $\begin{array}{l}\text { Control of technical condition and current maintenance } \\
\text { of trams }\end{array}$ & $\begin{array}{r}1,625.00 \\
\text { (volunteering) }\end{array}$ & $10,692.93$ \\
\hline $\begin{array}{l}\text { Repairs and maintenance of trams and removing the } \\
\text { effects of traffic accidents, including derailments }\end{array}$ & $33,244.64$ & 522.20 \\
\hline Printing of tickets, leaflets, timetables & $2,216.95$ & 838.48 \\
\hline Insurance & $1,425.00$ & $9,547.44$ \\
\hline Administrative costs & $2,550.00$ & $54,798.89$ \\
\hline Total & $\mathbf{6 9 , 7 8 3 . 6 6}$ & \\
\hline
\end{tabular}

Source: author. 
of societies). Taking into account only the direct costs of running trams (power consumption, readiness of the technical emergency service, use of infrastructure, work of tram-drivers), the running of tram cars on Routes A and B (KSTM) cost 20,747.07 PLN, while on Routes C and D (TMW), 19,724.08 PLN. Taking into account the revenue from tickets in 2018 (Table 1), Heritage Tram Lines have no chance of surviving without subsidies from the Municipal Office of Wrocław. This is how it has worked from the beginning, however we have to remember that the subsidy is variable from year to year and has ranged from 40,000 PLN to 120,000 PLN. In addition to these costs, the printing of tickets, the maintenance of trams and the work of guides, who have already become an important element of the offer, must be taken into account at least. In 2018, the subsidy for operation amounted to 100,000 PLN to be split in half between both carriers. This allowed a slightly more attractive offer to be created than in the previous year (e.g. a greater number of runs, including runs with a guide service, leaflets on the history of tram communication in Wrocław, generally more leaflets and timetables). It should also be remembered that the Lines support historic rolling stock, which needs to be maintained in a special way. Repairs in the event of a breakdown can be extremely expensive and at the same time must be carried out as soon as possible to ensure the continuity of operation. Neither association has extensive technical facilities that would allow complicated repairs, hence some works are out-sourced to companies with experience in work on technical monuments (all tram cars are entered in the register of monuments).

Based on these conditions for the operation of Heritage Tram Lines, and taking into account other elements of the Wrocław tourist offer, a SWOT analysis has been developed (Table 5). The tourist attraction presented certainly stands out due to its originality, in particular through the use of historic vehicles, i.e. an element of the cultural heritage of the city, for sightseeing. The high price of tickets and the limited scope of additional attractions, however, means that its competitiveness in relation to other ways of getting to know Wrocław (e.g. Melex trips) is not too high.

\section{CONCLUSIONS}

As noted by Meyer (2011, p. 15), "nowadays means of transport are increasingly becoming independent tourist attractions, being the destination of tourist trips" (see also Meyer, 2009). This is due to the fact that transport relatively quickly, apart from the performance of the connecting function, has become one of the attractions associated with a tourist trip (see e.g. Maćkowiak, 2015; Pawlusiński, 2007). Heritage Tram Lines, which have

Table 5. SWOT analysis for Heritage Tram Lines

\begin{tabular}{|c|c|}
\hline Strengths & Weaknesses \\
\hline $\begin{array}{l}\text { - use of authentic heritage to move around the city } \\
\text { - a convenient way to see the most important sights in } \\
\text { a short time } \\
\text { - location of stops at the most important monuments and } \\
\text { attractions } \\
\text { - variety of vehicles running on the Lines (they represent the } \\
\text { period from the interwar to the 1970s) } \\
\text { - the opportunity to travel either with a guide's commentary or } \\
\text { without } \\
\text { - no additional price for the guide service } \\
\text { - free leaflets on the history of tram communication in } \\
\text { Wrocław } \\
\text { - people serving the Lines are lovers of public transport } \\
\text { heritage }\end{array}$ & $\begin{array}{l}\text { - } \text { fairly high price for a trip, especially for individual tourists } \\
\text { - } \text { tourists must adapt to the departure times from individual } \\
\text { stops } \\
\text { - } \text { lack of access to some attractions or no opportunity to stop in } \\
\text { their vicinity } \\
\text { - } \text { lack of runs in the morning, when the residents of Wro- } \\
\text { cław go to Centennial Hall and Szczytnicki Park } \\
\text { - } \text { quite varied capacity of cars running on the Lines } \\
\text { - } \text { no opportunity to buy postcards or other souvenirs } \\
\text { - } \text { guide service only in Polish }\end{array}$ \\
\hline Opportunities & Threats \\
\hline $\begin{array}{l}\text { - establishing cooperation with managers of other attractions } \\
\text { and offering joint tickets, as well as joint promotion } \\
\text { - developing an additional offer, e.g. runs with live musicians or } \\
\text { thematic trips, devoted to selected elements of Wrocław or its } \\
\text { public transport history } \\
\text { - developing cooperation with guide groups and travel } \\
\text { agencies } \\
\text { - offering guide services in English and German on selected } \\
\text { days } \\
\text { - use of audioguides }\end{array}$ & $\begin{array}{l}\text { - competition from other means of moving around the city, } \\
\text { mainly Melex cars, which transport tourists not only around the } \\
\text { Old Town, but also to the Centennial Hall } \\
\text { - } \text { renovation of tramway tracks hindering the optimal design } \\
\text { of the routes } \\
\text { - } \text { repeatability of the offer - a similar route in the following } \\
\text { years (once used, no motivation to do it again) }\end{array}$ \\
\hline
\end{tabular}

Source: author. 
been running in Wrocław for 10 years, can undoubtedly be considered a tourist attraction. Firstly, the historic tram cars recall how transport has changed over the last century (the oldest tram car appearing on the Lines represents the Linke-Hofmann Standard series, produced in 1925-1929; Jerczyński, 2001), secondly, they provide an attractive and efficient form of movement between attractions. In 2018, the offer was extended in relation to previous years, as a result of the introduction of a second carrier (Urban Transport Enthusiasts Club) alongside the previous one (Wrocław Admirers Society). In addition to changes in the operation important for passengers (including a larger number of stops as part of the 'hop on-hop off' offer, new types of tickets, a greater number of runs with a guide, and visually more attractive graphic materials), the result was the acquisition of quite detailed data regarding usage. Information on the sale of tickets showed that the Lines were most popular in July and August, but the average percentage of seating places taken up is around $40 \%$, so the potential is not fully used. It is surprising that runs with a guide service were not necessarily the most popular. New types of tickets (family, return) were quite popular because they were more advantageous in terms of prices, important in view of the price increase in relation to the previous year (resulting from a decision of the city authorities). It is also clear that the carriers would not be able to maintain the Lines based only on the revenues from tickets (and possibly the sale of souvenirs), without subsidies.

An analysis of the operation of Heritage Tram Lines in 2018 allowed certain conclusions to be drawn aimed at improving the offer. Despite less interest in June and September, it seems advisable that it should start running as soon as the long weekend at the beginning of May, and finish at the turn of October (although at those times it may have a lower frequency). Thanks to this, it will be present not only in the city landscape but also in the awareness of both the inhabitants of Wroclaw and tourists who, consequently, may contribute to an increase in average revenues. Runs to the Centennial Hall before noon could be considered to enable people willing to spend an entire day in this attractive part of the city to get there. One-day (or even weekend) tickets should be introduced making it possible to take full advantage of the 'hop on-hop off' offer. Combined tickets including Heritage Tram Lines and selected other tourist attractions owned by the city authorities, in particular the Zoological Garden and Centennial Hall, are also worth considering. Various types of souvenir (such as postcards, key rings, models of vintage trams) should be available, which would make the offer more comprehensive and would also have an impact on the financial result. It is also worth considering other forms of making the trip more attractive.
A guide's commentary is a standard form used on most tourist routes, although in the case of Wrocław it is surprising that runs with a guide are not more popular than those without. Rides with live musicians on board could be considered. The Urban Transport Enthusiasts Club has been doing such runs since September 2017 in cooperation with one of the jazz clubs. They are very popular, but until now they have been free of charge because they are promoting and popularizing or taking place as a part of various cultural events. The question is, would tourists and the inhabitants of Wroclaw be eager for this type of ride for a fee?

Tourist tram lines operated by historic rolling stock attract tourists with the opportunity for direct contact with heritage, in this case the heritage of technology which has been gaining popularity in recent years. However, the group of lovers of historic means of transport is limited, and in order to attract a wider group of customers and ensure economic profitability, it is necessary to combine the core product (Kaczmarek, Stasiak, Włodarczyk, 2010), i.e. a historic tram ride, with additional attractions. The simplest option is the opportunity to explore the city from the windows of the vehicle together with the guide's commentary, but there can also be attempts to combine technical culture with popular culture, for example performances of bands in a tram car. It seems that historical trams so far are able to independently generate tourism in cities where they influence its genius loci, e.g. Lisbon or San Francisco. They have not fulfilled such a role so far in Wrocław.

\section{ENDNOTES}

${ }^{1}$ Wrocław's historic trams mostly have their own names.

2 Settlement periods had different length, hence it is difficult to draw any conclusions based on these data regarding the variability in time of TMW's revenues from tickets for travel on the Heritage Tram Lines.

${ }^{3}$ In the literature on mass transport, the notion of filling is often used in this context (see i.a. Gill, Gramza, 2016; Starowicz, 2007; Stasiak, Kiciński, 2014).

${ }^{4}$ The range of values is based on the assumption that three to five people could travel on a family ticket. In the case of return tickets, the number of passengers is doubled the number of tickets sold, as each person travelled on two courses.

\section{BIBLIOGRAPHY}

Ashworth, G.J. (1992). Is there an urban tourism? Tourism Recreation Research, 17 (2), 3-8.

Bufe, S. (ed.) (1992). Strassenbahnen in Schlesien. Egglham: BufeFachbuch-Verlag. 
Cudny, W. (2018). Car tourism. Cham: Springer.

Cudny, W., Horňák, M. (2016). The tourist function in a car factory Audi Forum Ingolstadt example. Bulletin of Geography. Socioeconomic Series, 33, 23-38.

Gill, A., Gramza, G. (2016). Poziom napełnienia stref dla osób stojących w tramwaju jako miernik ocen jakości ich zabudowy i atrakcyjności dla pasażerów. Autobusy: Technika, Eksploatacja, Systemy Transportowe, 12, 612-617.

Goranczewski, B., Puciato, D. (2010). SWOT analysis in the formulation of tourism development strategies for destinations. Tourism/Turyzm, 20 (2), 45-53.

Jerczyński, M. (2001). Wrocławskie wagony tramwajowe typu standard. Świat Kolei, 6, 44-48.

Kaczmarek, J., Stasiak, A., Włodarczyk, B. (2010). Produkt turystyczny. Pomyst - Organizacja - Zarzadzanie. Warszawa: PWE.

Kołodziejczyk, K. (2011). Historia, stan i perspektywy wykorzystania $\mathrm{w}$ turystyce dziedzictwa wrocławskiej komunikacji tramwajowej. In: K. Widawski (ed.), Turystyka kulturowa na Dolnym Śląsku - wybrane aspekty. Vol. 2 (pp. 119-150). Wrocław: Instytut Geografii i Rozwoju Regionalnego Uniwersytetu Wrocławskiego.

Kołodziejczyk, K. (2018). Potencjał polskich miast pod względem zabytkowych tramwajów i ich wykorzystanie w turystyce. Ekonomiczne Problemy Turystyki, 2 (42), 209-224. DOI 10.18276/ept.2018.2.42-20.

Kowalczyk, A. (2005). Nowe formy turystyki miejskiej. Prace i Studia Geograficzne, 35, 155-197.

Kruczek, Z. (2011). Atrakcje turystyczne. Fenomen, typologia, metody badań. Kraków: Proksenia.

Krzeszowski, J. (2018). Startuje zabytkowa linia tramwajowa. Retrieved from: https://www.Wrocław.pl/zabytkowa-liniatramwajowa (15.06.2018).

Lewandowski, K., Molecki, B. (eds) (2006). Tramwaje we Wrocławiu 1877-2006. Wrocław: Oficyna Wydawnicza Politechniki Wrocławskiej.

Lipińska, I. (2011). Turystyka dziedzictwa kulturowego - wybrane aspekty ochrony prawnej parku kulturowego. Turystyka Kulturowa, 3, 14-27.

Maciejewski, J. (2004). O wrocławskich tramwajach. Wrocław: Oficyna Wydawnicza Oddziału Wrocławskiego PTTK „Sudety”.

Maćkowiak, R. (2015). Wykorzystanie transportu w turystyce. In: B. Meyer (ed.), Obstuga uczestników turystyki i rekreacji. Wybrane aspekty (pp. 157-159). Warszawa: Difin.

Marak, J., Wyrzykowski, J. (2010). Klasyfikacja ruchu turystycznego. In: J. Wyrzykowski, J. Marak (eds), Turystyka w ujęciu interdyscyplinarnym (pp. 20-29). Wrocław: Wyższa Szkoła Handlowa.

Matczak, A. (1989). Problemy badania funkcji turystycznej miast Polski. Funkcja turystyczna. Acta Universitatis Lodziensis. Turyzm, 5, 27-39.

Mehring, A. (2017). Komunikacja miejska w obsłudze obiektów turystycznych i rekreacyjnych. Progress. Journal of Young Researchers, 1, 84-95. DOI 10.4467/25439928PS.17.007.6513.

Meyer, B. (2009). Historyczne i współczesne znaczenie transportu w turystyce. Problemy Transportu i Logistyki, 7, 149-159.

Meyer, B. (2011). Modyfikacja funkcji pełnionych przez podstawowe formy obsługi ruchu turystycznego. Ekonomiczne Problemy Turystyki, 16, 9-24.
Meyer, B. (2015). Transport jako atrakcja turystyczna. In: B. Meyer (ed.), Obstuga uczestników turystyki i rekreacji. Wybrane aspekty (pp. 173-177). Warszawa: Difin.

Mika, M. (2007a). Turystyka miejska. In: W. Kurek (ed.), Turystyka (pp. 319-328). Warszawa: Wydawnictwo Naukowe PWN.

Mika, M. (2007b). Klasyfikacja ruchu turystycznego. In: W. Kurek (ed.), Turystyka (pp. 197-198). Warszawa: Wydawnictwo Naukowe PWN.

Mikos von Rohrscheidt, A. (2008). Turystyka kulturowa. Fenomen, Potencjat. Perspektywy. Gniezno: Milenium.

Nowacki, M. (2000). Analiza potencjału atrakcji krajoznawczych na przykładzie Muzeum Narodowego w Szreniawie. In: A. Szwichtenberg, E. Dziegieć (eds), Przemyst turystyczny (pp. 147-164). Koszalin: Politechnika Koszalińska.

Ostatnie weekendy kursowania wroctawskiej Zabytkowej Linii Tramwajowej (2018). Retrieved from: https://www.tuWrocław. com/wiadomosci,ostatnie-weekendy-kursowania-Wrocławkiej-zabytkowej-linii-tramwajowej,wia5-3266-43428.html (24.09.2018).

Page, S. (1995). Urban tourism. London-New York: Routledge.

Pawlusiński, R. (2007). Transport w turystyce. In: W. Kurek (ed.), Turystyka (pp. 164-177). Warszawa: Wydawnictwo Naukowe PWN.

Sala, J. (2012). Miasta jako cel podróży turystycznych w Polsce. In: T. Żabińska (ed.), Turystyka na obszarach miejskich: uwarunkowania rozwoju, narzędzia promocji (pp. 20-32). Katowice: Wydawnictwo Uniwersytetu Ekonomicznego w Katowicach.

Sielicki, T. (2012a). Przez wrocławskich ulic sto... Historia tramwajów we Wrocławiu. Wrocław: Muzeum Miejskie Wrocławia.

Sielicki, T. (2012b). Przez Sępolno, Zalesie i Krzyki - historia wrocławskich tramwajów. In: M. Derwich (ed.), O historii Wrocławia i Ślaska inaczej. Vol. 1 (pp. 81-105). Wrocław: Wrocławskie Towarzystwo Miłośników Historii.

Sielicki, T. (2013). Historyczny tabor komunikacyjny we Wroctawiu. Wrocław: Centrum Badań nad Miastem (typescript).

Sielicki, T. (2017). Wroctawskie tramwaje konne. Łódź: Wydawnictwo Księży Młyn.

Stasiak, P., Kiciński, M. (2014). Badania i ocena stopnia wykorzystania taboru autobusowego w przedsiębiorstwie ZUK Rokbus Spółka z o.o. Logistyka, 3, 5967-5975.

Starowicz, W. (2007). Jakość przewozów w miejskim transporcie zbiorowym. Kraków: Wydawnictwo Politechniki Krakowskiej.

Turystyka-motoryzacyjna.pl. Retrieved from: https://www.turystyka-motoryzacyjna.pl/ (23.09.2018).

Tylińska, R. (2005). Analiza SWOT instrumentem w planowaniu rozwoju. Warszawa: WSIP.

Wojcieszak, J. (1993). 100 lat tramwajów elektrycznych we Wroctawiu. Poznań: Poznański Klub Modelarzy Kolejowych.

Wroctawska Zabytkowa Linia Tramwajowa atrakcją dla turystów i mieszkańców (2018). Retrieved from: https:/ / www.tuWrocław. com/ wiadomosci,Wrocławska-zabytkowa-linia-tramwajowaatrakcja-dla-turystow-i-mieszkancow,wia5-3266-42475.html (24.09.2018).

Zabytkowa Linia Tramwajowa kursuje jeszcze przez trzy weekendy (2018). Retrieved from: http://Wrocław.wyborcza.pl/Wrocław/7,35771,23816471,zabytkowa-linia-tramwajowa-kursujejeszcze-przez-trzy-weekendy.html (24.09.2018). 


\section{ATTACHMENTS}

Number of tickets sold on routes A and B of the Heritage Tram Lines during the second weekend (23-24.06.2018) of the operation of the line divided into types of tickets and individual runs

\begin{tabular}{|c|c|c|c|c|c|c|c|}
\hline \multirow{3}{*}{ Tram run } & \multicolumn{3}{|c|}{ One-way tickets } & \multicolumn{3}{|c|}{ Return tickets } & \multirow{3}{*}{ Total } \\
\hline & full -price & concessionary & family & full -price & concessionary & family & \\
\hline & 8 PLN & 4 PLN & 16 PLN & 8 PLN & 4 PLN & 24 PLN & \\
\hline $12: 00$ & 4 & 1 & 0 & 5 & 4 & 1 & 15 \\
\hline $13: 15$ & 0 & 0 & 0 & 1 & 0 & 0 & 1 \\
\hline $14: 00$ & 6 & 2 & 0 & 2 & 1 & 0 & 11 \\
\hline $15: 15$ & 1 & 4 & 0 & 0 & 0 & 1 & 6 \\
\hline $16: 00$ & 1 & 1 & 0 & 5 & 5 & 0 & 12 \\
\hline $17: 15$ & 1 & 0 & 0 & 0 & 0 & 0 & 1 \\
\hline Total & 13 & 8 & 0 & 13 & 10 & 2 & 46 \\
\hline
\end{tabular}

Source: author.

Number of tickets sold on routes A and B of the Heritage Tram Lines during the penultimate weekend (01-02.09.2018) of the operation of the line divided into types of tickets and individual runs

\begin{tabular}{|c|c|c|c|c|c|c|c|}
\hline \multirow{3}{*}{ Tram run } & \multicolumn{3}{|c|}{ One-way tickets } & \multicolumn{3}{|c|}{ Return tickets } & \multirow{3}{*}{ Total } \\
\hline & full -price & concessionary & family & full -price & concessionary & family & \\
\hline & 8 PLN & 4 PLN & 16 PLN & 8 PLN & 4 PLN & 24 PLN & \\
\hline 12:00 & 7 & 1 & 2 & 3 & 4 & 1 & 18 \\
\hline 13:15 & 2 & 3 & 2 & 0 & 0 & 0 & 7 \\
\hline 14:00 & 4 & 4 & 0 & 0 & 0 & 0 & 8 \\
\hline 15:15 & 8 & 6 & 1 & 0 & 0 & 1 & 16 \\
\hline 16:00 & 3 & 1 & 1 & 4 & 0 & 2 & 11 \\
\hline $17: 15$ & 2 & 0 & 1 & 0 & 0 & 0 & 3 \\
\hline Total & 26 & 15 & 7 & 7 & 4 & 4 & 63 \\
\hline
\end{tabular}

Source: author. 